\title{
INFLUENCE OF CLAST AXIAL RATIO ON MACROFABRIC STRENGTH IN PERIGLACIAL COLLUVIUM
}

\author{
SUSAN W.S. MILLAR ${ }^{1}$ AND FREDERICK E. NELSON ${ }^{2}$ \\ ${ }^{1}$ Department of Geography, Maxwell School, Syracuse University, Syracuse, New York 13244, U.S.A. \\ e-mail:swmillar@maxwell.syr.edu \\ ${ }^{2}$ Department of Geography and Center for Climatic Research, University of Delaware Newark, Delaware 19716, U.S.A.
}

\begin{abstract}
Samples of fabric data collected from periglacial solifluction lobes in central Alaska show a systematic, positive relation between clast axial ratio and fabric strength. Samples composed of clasts with low $a: b$ axial ratios have relatively low fabric strength. Restricting sampling to clasts with axial ratios of $1.5: 1$ or higher increases fabric strength and decreases its variability. To enhance comparability between fabric studies and the utility of fabric interpretation, sampling should be restricted to clasts with relatively large $(\geq 1.5: 1)$ axial ratios.
\end{abstract}

\section{INTRODUCTION}

Reconstruction of Quaternary paleoenvironments relies on a convergence-of-evidence approach requiring data from many diverse sources. Analysis of clast orientation in a sediment or soil matrix (macrofabric analysis) is a common field-based technique that provides information about depositional environment, flow regime, and slope processes (e.g., Lundqvist 1949; Lindsay 1968; Mills 1983, 1987; Nelson 1985; Major 1998).

Although technological and interpretive advances in fabric analysis (e.g., Fisher et al. 1987; Benn 1994) have provided progressively more detailed information about the nature of processes on hillslopes, their relative intensity, and the deformation of colluvial masses, development of general theory and a comprehensive database have been hampered by the fact that sampling procedures vary considerably between investigators (Mills 1991; Bertran et al. 1997).

The utility of macrofabric analysis has been questioned on several grounds. Criticisms include inconsistency in field measurement techniques (Hill 1968), inability to differentiate between depositional environments (Bennett et al. 1999), and the influence of sampling procedures and criteria (Kjær and Krüger 1998; Major 1998; Millar and Nelson 2001a,b). Such concerns should be considered carefully, and confounding factors that could affect resultant fabrics addressed.

Using Zingg's categories of disc, sphere, blade, and rod, Drake (1974) illustrated that pebble shape can influence macrofabrics developed in glacial till. In a study of solifluction in the Japanese Alps using the same categories, Yamamoto (1989) found a statistically significant relation between clast shape and fabric characteristics. Rod-shaped particles, which have the greatest degree of elongation in this classification, were most likely to be oriented parallel to the direction of flow. Yamamoto concluded that axial ratio exerts an appreciable effect on fabric strength, a finding with important implications for sampling design in subsequent studies of colluvial macrofabrics.

Multi-scale approaches to geomorphic problems have gained wide acceptance (e.g., Schumm 1991, p. 48; Bauer et al. 1999). To be effective, well-designed sampling programs must be implemented at each scale of investigation, or cumulative errors of substantial magnitude may develop. To assess the influence of sampling decisions at different scales in macrofabric studies, Millar and Nelson (2001b) classified sampling considerations along a continuum of spatial scale: microscale decisions involve such factors as the size and geometry of clasts selected for measurement; mesoscale considerations include selection of topographic position and orientation of the sampling surface; and macroscale decisions involve the spacing and geographic interrelations between sampling locations. This note is concerned primarily with the first class by demonstrating the systematic effect of clast axial ratio on the strength of macrofabrics in sediments affected by periglacial solifluction. The implications may extend beyond studies of periglacial colluvium to sampling considerations during examination of genetic and depositional processes in glacial, fluvial, and other colluvial environments.

\section{METHODS}

\section{Field Procedures}

Data were collected from a series of periglacial solifluction ("gelifluction") lobes and terraces (Fig. 1) near Eagle Summit $\left(65.5^{\circ} \mathrm{N}, 145.5^{\circ} \mathrm{W}\right)$ in the Yukon-Tanana Upland physiographic province of interior Alaska (Wahrhaftig 1965). The features are active, as evidenced by small shrubs bent or partially buried by slope materials, and by displacement of markers installed in the early 1960s to monitor slope movements (Haugen and Miller 1963).

Samples examined in this study are a subset of a larger collection of fabric data from sites selected across the terrain at Eagle Summit using a stratified systematic unaligned sampling design (Berry and Baker 1968; Iachan 1985). The sampling program was formulated to assess the variability of fabrics on heterogeneous slopes, many of which were mantled with well-developed solifluction lobes, an important consideration in a paleoenvironmental context (Millar and Nelson 2001a). To enable standardized comparisons for this study, analysis was restricted to data obtained from 38 sites that displayed well-defined lobate solifluction forms. Sampling locations included a variety of micro-environmental settings, including lobe-front riser, lateral margins, and upslope position on the tread (Table 1).

Fifty observations of plunge and plunge azimuth of the $a$ axes of elongate clasts were made at each sampling location (Fig. 2). Samples were obtained from the floor of $1 \mathrm{~m} \times 1 \mathrm{~m} \times 1 \mathrm{~m}$ excavations, between 25 and $50 \mathrm{~cm}$ depth, as detailed in Millar and Nelson (2001b). The $a, b$, and $c$ axes of each clast were identified and measured following the method detailed by Andrews (1971, p. 13). Clasts were selected on the basis of the existence of a well-defined major axis.

Eight samples from an earlier study by Nelson (1985) are included in

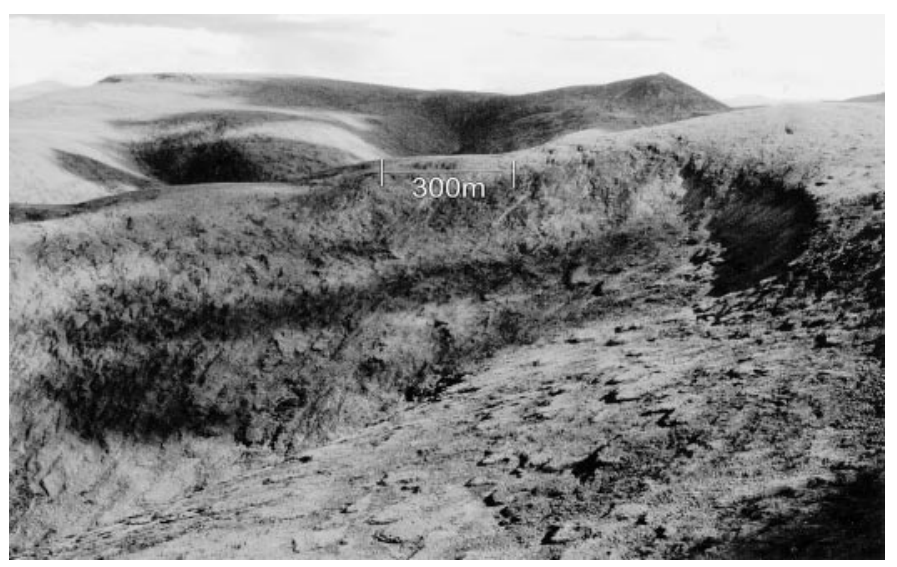

FIG. 1.-View of representative lobes on sampled slopes at Eagle Summit, Alaska. Distance indicated by bar scale is approximate. View is from the north-center of map shown in Figure 2. 
TABLE 1.-Statistical summary of Eagle Summit macrofabric data.

\begin{tabular}{|c|c|c|c|c|c|c|c|c|c|c|}
\hline \multirow[b]{2}{*}{ Site } & \multirow[b]{2}{*}{ Lobe Position } & \multirow{2}{*}{$\begin{array}{c}\text { Mean } \\
a: b \\
\text { ratio }\end{array}$} & \multicolumn{3}{|c|}{ Unfiltered Data } & \multirow[b]{2}{*}{$n$} & \multirow{2}{*}{$\begin{array}{l}\text { Mean } \\
a: b \\
\text { ratio }\end{array}$} & \multicolumn{3}{|c|}{ Filtered Data } \\
\hline & & & $\overline{\bar{\tau}_{1}}$ & $\bar{\tau}_{3}$ & $\zeta$ & & & $\overline{\tau_{1}}$ & $\overline{\tau_{3}}$ & $\zeta$ \\
\hline 1 & left side tread surface & 1.67 & 0.112 & 0.634 & 1.734 & 38 & 1.99 & 0.121 & 0.607 & 1.615 \\
\hline 2 & lobe & 1.67 & 0.126 & 0.647 & 1.636 & 36 & 1.89 & 0.113 & 0.657 & 1.759 \\
\hline 3 & on small lobe & 1.57 & 0.084 & 0.600 & 1.966 & 28 & 2.02 & 0.061 & 0.626 & 2.325 \\
\hline 4 & center riser on small lobe & 1.69 & 0.093 & 0.494 & 1.670 & 35 & 1.98 & 0.082 & 0.535 & 1.876 \\
\hline 5 & right tread of lobe & 1.93 & 0.670 & 0.786 & 2.462 & 40 & 2.28 & 0.063 & 0.821 & 2.565 \\
\hline 6 & upslope of small lobe & 1.71 & 0.076 & 0.507 & 1.898 & 35 & 2.02 & 0.034 & 0.586 & 2.861 \\
\hline 7 & upslope of tread & 1.91 & 0.072 & 0.804 & 2.413 & 40 & 2.29 & 0.071 & 0.818 & 2.450 \\
\hline 8 & on small lobe & 1.65 & 0.193 & 0.513 & 0.978 & 34 & 2.10 & 0.149 & 0.544 & 1.292 \\
\hline 9 & left back tread of small lobe & 1.64 & 0.199 & 0.462 & 0.842 & 32 & 1.97 & 0.199 & 0.506 & 0.936 \\
\hline 10 & right side tread & 1.67 & 0.142 & 0.599 & 1.439 & 30 & 2.26 & 0.101 & 0.673 & 1.897 \\
\hline $11 \mathrm{~A}$ & lobe riser & 1.74 & 0.092 & 0.674 & 1.991 & 34 & 2.18 & 0.067 & 0.734 & 2.392 \\
\hline $11 \mathrm{~B}$ & left riser & 1.87 & 0.148 & 0.655 & 1.487 & 38 & 2.19 & 0.119 & 0.700 & 1.775 \\
\hline $11 \mathrm{C}$ & right riser & 1.76 & 0.099 & 0.688 & 1.939 & 36 & 2.05 & 0.076 & 0.728 & 2.265 \\
\hline $11 \mathrm{D}$ & nose center & 1.84 & 0.120 & 0.642 & 1.677 & 38 & 2.29 & 0.118 & 0.652 & 1.710 \\
\hline $11 \mathrm{E}$ & tread center & 1.87 & 0.114 & 0.551 & 1.576 & 39 & 2.51 & 0.108 & 0.530 & 1.587 \\
\hline 12 & slightly right of tread central axis & 1.67 & 0.118 & 0.699 & 1.779 & 36 & 1.95 & 0.118 & 0.694 & 1.774 \\
\hline 13 & slightly left of center on tread & 1.73 & 0.180 & 0.488 & 0.997 & 39 & 2.10 & 0.192 & 0.467 & 0.892 \\
\hline 14 & center of small flat lobe & 1.68 & 0.090 & 0.802 & 2.187 & 38 & 2.05 & 0.094 & 0.799 & 2.135 \\
\hline 15 & lobe riser left side & 1.66 & 0.108 & 0.576 & 1.674 & 33 & 2.01 & 0.073 & 0.582 & 2.075 \\
\hline 16 & center of mid tread & 1.90 & 0.049 & 0.778 & 2.765 & 42 & 1.91 & 0.045 & 0.806 & 2.883 \\
\hline 17 & right center tread & 1.80 & 0.071 & 0.658 & 2.227 & 40 & 2.20 & 0.071 & 0.701 & 2.293 \\
\hline $18 \mathrm{~A}$ & near center of small flat lobe & 1.79 & 0.067 & 0.706 & 2.355 & 39 & 2.21 & 0.065 & 0.755 & 2.456 \\
\hline \multirow[t]{2}{*}{$18 \mathrm{~B}$} & tread center riser $20 \mathrm{~cm}$ depth & & & & & & & & & \\
\hline & below duff & 1.92 & 0.137 & 0.636 & 1.535 & 42 & 2.20 & 0.151 & 0.595 & 1.373 \\
\hline \multirow[t]{2}{*}{$18 \mathrm{C}$} & tread center riser $50-70 \mathrm{~cm}$ & & & & & & & & & \\
\hline & depth below duff & 1.80 & 0.084 & 0.662 & 2.064 & 40 & 2.15 & 0.081 & 0.680 & 2.133 \\
\hline \multirow[t]{2}{*}{$18 \mathrm{D}$} & back center tread $20 \mathrm{~cm}$ depth & & & & & & & & & \\
\hline & below duff & 1.78 & 0.078 & 0.721 & 2.224 & 42 & 2.02 & 0.058 & 0.758 & 2.569 \\
\hline \multirow[t]{2}{*}{$18 \mathrm{E}$} & back center tread $50-70 \mathrm{~cm}$ & & & & & & & & & \\
\hline & depth below duff & 1.76 & 0.069 & 0.775 & 2.419 & 37 & 2.07 & 0.072 & 0.767 & 2.364 \\
\hline $18 \mathrm{~F}$ & left riser & 1.72 & 0.072 & 0.748 & 2.341 & 37 & 2.10 & 0.056 & 0.774 & 2.623 \\
\hline $18 \mathrm{G}$ & right riser & 1.71 & 0.132 & 0.680 & 1.639 & 36 & 2.06 & 0.121 & 0.693 & 1.747 \\
\hline $18 \mathrm{H}$ & nose center & 1.76 & 0.154 & 0.605 & 1.368 & 37 & 1.97 & 0.169 & 0.606 & 1.277 \\
\hline $18 \mathrm{I}$ & tread center & 1.93 & 0.106 & 0.777 & 1.992 & 41 & 2.01 & 0.099 & 0.770 & 2.052 \\
\hline 19 & upslope of tread & 1.62 & 0.209 & 0.422 & 0.703 & 35 & 2.10 & 0.225 & 0.423 & 0.631 \\
\hline \multirow[t]{2}{*}{20} & break in slope on riser-tread & 1.77 & 0.138 & 0.490 & 1.267 & 38 & & & & \\
\hline & of lobe & & & & & & 2.36 & 0.161 & 0.479 & 1.087 \\
\hline $21 \mathrm{~A}$ & left riser & 1.72 & 0.103 & 0.577 & 1.723 & 36 & 2.07 & 0.083 & 0.565 & 1.922 \\
\hline $21 \mathrm{~B}$ & right tread of lobe & 1.80 & 0.106 & 0.771 & 1.984 & 39 & 2.07 & 0.116 & 0.751 & 1.865 \\
\hline $22 \mathrm{~A}$ & left riser & 1.82 & 0.061 & 0.788 & 2.559 & 38 & 2.20 & 0.040 & 0.777 & 2.957 \\
\hline $22 \mathrm{~B}$ & right riser & 1.77 & 0.119 & 0.550 & 1.534 & 38 & 2.12 & 0.119 & 0.617 & 1.650 \\
\hline $22 \mathrm{C}$ & nose center & 1.71 & 0.076 & 0.621 & 2.101 & 36 & 2.01 & 0.076 & 0.618 & 2.090 \\
\hline $22 \mathrm{D}$ & tread center & 1.81 & 0.105 & 0.562 & 1.678 & 39 & 2.11 & 0.115 & 0.591 & 1.636 \\
\hline
\end{tabular}

Sample locations are indicated in Figure 2. Letters appended to sample numbers indicate sites from which multiple samples were obtained. Symbol definitions are provided in text.

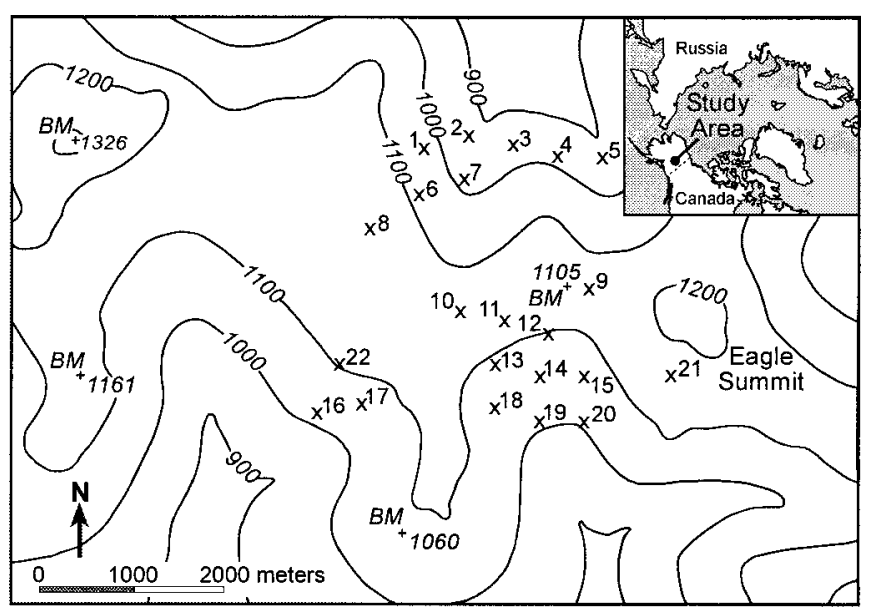

FIg. 2.-Generalized contour map of Eagle Summit study area, showing sampling locations relative to U.S. Geological Survey benchmarks. Symbol on inset shows location of study area in Alaska and circum-Arctic region. the analysis. These samples were collected from the semivertical, upslope faces of shallow pits dug in solifluction lobes located in the same general area. Details are provided in Nelson (1985, p. 24). Only clasts with $a: b$ axial ratios greater than 2:1 were sampled. Clast dimensions were not recorded.

\section{Data Analysis}

Following procedures and notation developed in Mardia (1972, Chapter 8) and Fisher et al. (1987, Chapter 3), eigenvalues and eigenvectors were extracted from the symmetric $3 \times 3$ "orientation matrix" $\mathrm{T}$ formed by the sums of squares and products of direction cosines from the measurements of plunge and plunge azimuth. The eigenvectors $\mathrm{t}_{i}$, where $i=1,2$, 3 of $\mathrm{T}$ represent the mutually orthogonal axes of minimum, intermediate, and maximum clustering of the observations, respectively. The corresponding normalized eigenvalues $\bar{\tau}_{i}$, such that $\bar{\tau}_{3} \geq \bar{\tau}_{2} \geq \bar{\tau}_{1}$, provide a measure of the relative length of these axes. The data are represented graphically in Figure 3, a statistical summary is provided in Table 1, and sample position in Woodcock's (1977) eigenspace is shown in Figure 4.

Figure 5A shows the relation between clast axial ratio and Woodcock's (1977) strength parameter $\zeta$, given by $\zeta=\log \left(\bar{\tau}_{3} / \bar{\tau}_{1}\right)$, a measure of the degree of fabric clustering or tightness, for the Eagle Summit samples. The 

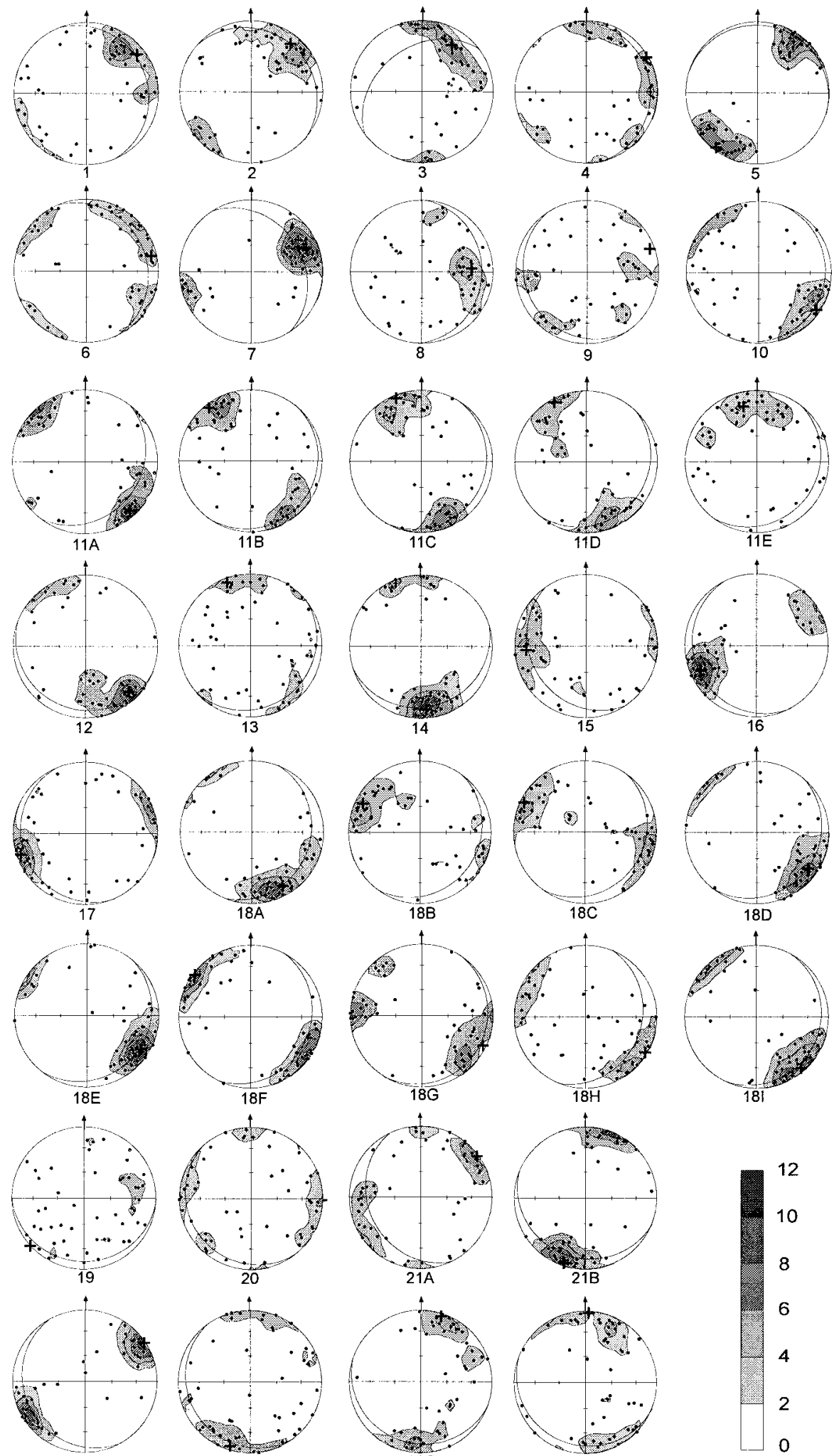

FIG. 3.-Eagle Summit macrofabric data, plotted on lower hemisphere, Lambert equal-area projections. Data were rotated into the plane of the local slope (Nelson 1985) and contoured using Starkey's (1977) point-counting method. Each counting circle occupied $2 \%$ of the projective net (Stesky 1998). Shading density is standardized between nets; isolines represent 2, $4,6,8,10$, and 12 points per counting circle. Position of principal eigenvector is indicated.

plot includes data from the mean of the eight sites sampled by Nelson (1985) in the same locality. Although there is considerable scatter, Pearson correlation coefficients indicate a statistically significant relation $(r=$ 0.541, $\alpha=0.001$ ) between fabric strength and clast axial ratio (Table 2).
The reduced major axis (RMA) line (Till 1974) in Figure 5A indicates the positive, linear form of the relation between axial ratio and fabric strength.

To examine the effect of clast axial ratio on fabric more closely, each of the Eagle Summit samples was filtered to remove all clasts with axial 


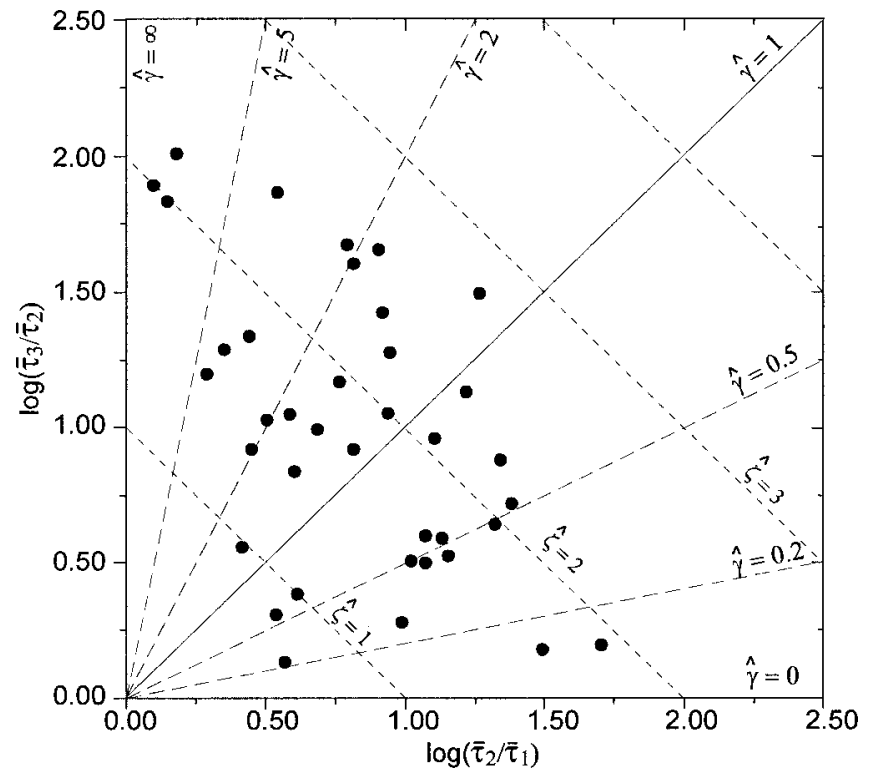

FIG. 4.-Eigenspace, following Woodcock (1977), of Eagle Summit lobe fabric data.

ratios less than 1.5:1 (Fig. 5B). This ratio was selected because it is frequently used (Table 3) and to ensure adequate sample size for statistical analysis. Correlation results are given in Table 2. There is no apparent relation between clast axial ratio and fabric strength in the filtered data set.

\section{INTERPRETATION}

The relation between clast elongation and fabric characteristics has been addressed only indirectly in studies of colluvial macrofabrics. Although in many cases researchers have limited axial ratios to some preset range, there
TABLE 2.-Pearson's correlation of axial ratio and fabric strength.

\begin{tabular}{|c|c|c|c|c|}
\hline & $n$ & Pearson $r$ & Student's $t$ & Probability \\
\hline $\begin{array}{l}\text { All lobe samples collected in } \\
\text { present study }\end{array}$ & 38 & 0.429 & 2.748 & 0.007 \\
\hline $\begin{array}{l}\text { Lobes in this study, plus av- } \\
\text { erage of Nelson's data } \\
\text { (1985) from } 8 \text { lobe sites }\end{array}$ & 39 & 0.541 & 3.790 & 0.001 \\
\hline $\begin{array}{l}\text { Samples with only clast } a: b \\
\geq 15\end{array}$ & 38 & 0095 & 0.902 & 0.428 \\
\hline
\end{tabular}

is no consensus about a preferred $a: b$ ratio for sampled clasts. An $a: b$ ratio of 1.5:1 is frequently used as a threshold value for inclusion in a sample. Choice of this value enables the operator to identify elongate clasts readily, although the characteristics of the deposit and its source material may dictate what the axial ratio can be. The range of $a: b$ limits in macrofabric studies is extensive: examples are listed in Table 3.

Theoretical considerations indicate that restricting the range of axial ratios is desirable. According to Jeffery's (1922) consideration of the angular velocity of prolate objects in a viscous flow, the degree of clast elongation affects the rate of its rotation. Simulations by Lindsay (1968) showed considerable agreement between Jeffery's formulation and observed fabrics in mudflow deposits. At the microscopic level, Bertran (1993) elaborated this further, suggesting that fabrics show stronger preferred orientation when composed of more elongated clasts. Prolate clasts rotate more slowly when oriented normal to the velocity gradient than when at some angle to it, whereas equant clasts show little variation in angular velocity as they rotate. With increasing elongation, stones begin to behave as passive markers, spending most of the time normal to the velocity gradient (Bertran 1993).

Field evidence from Eagle Summit supports the theoretical considerations outlined above and indicates the existence of a direct relation between average clast axial ratio and fabric strength in materials affected by periglacial solifluction. The absence of such a relation in the Eagle Summit filtered data indicates the possible existence of thresholds involving clast geometry in generating tightly clustered fabrics.
A

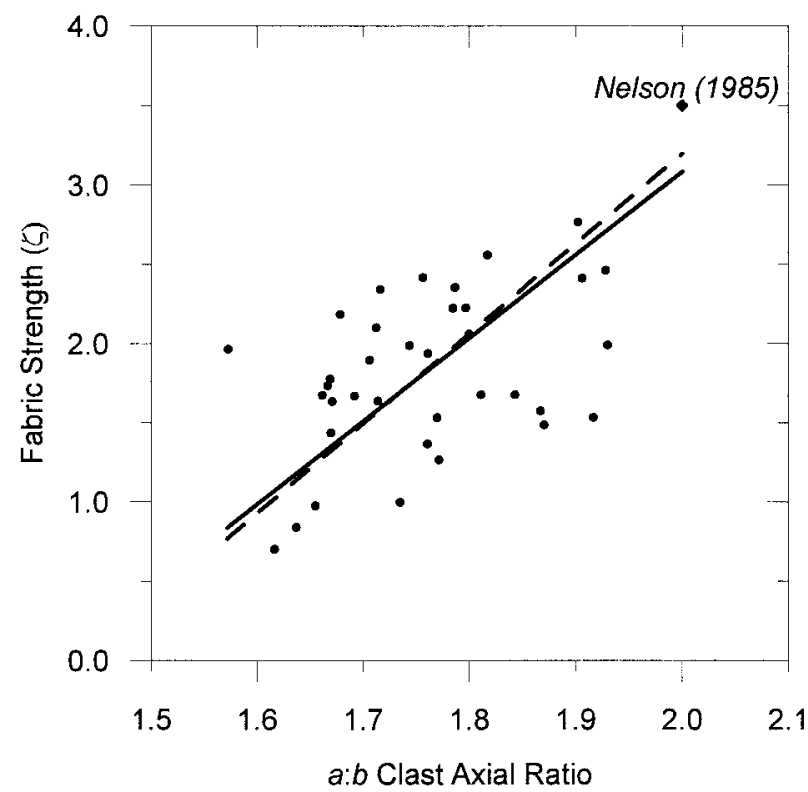

B

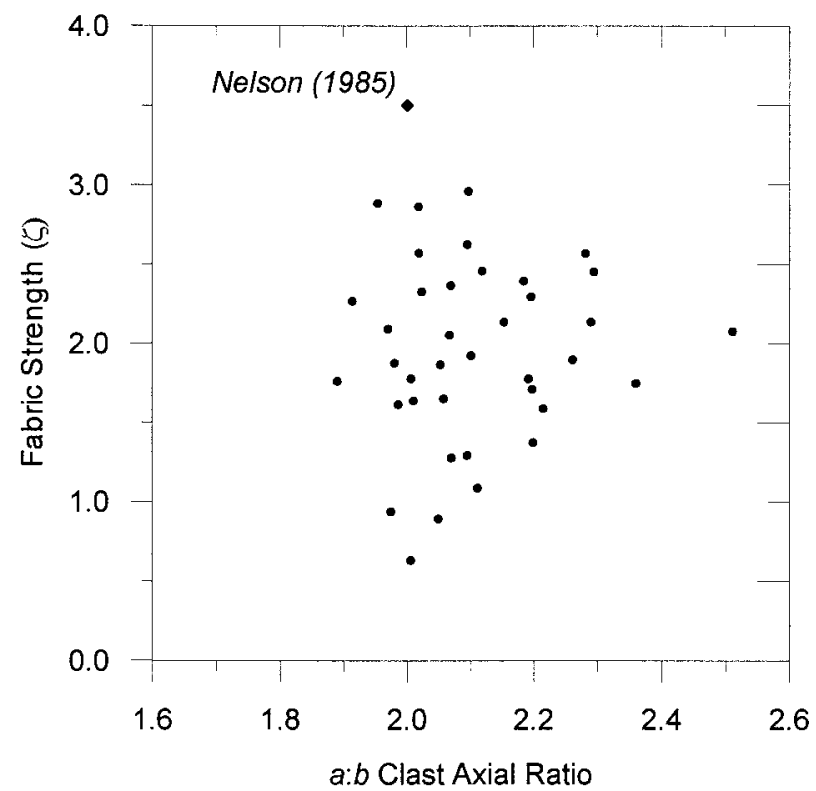

FIg. 5.-Plots showing relation between $a: b$ clast axial ratio and fabric strength. A) Solid line is RMA for lobe sites with equation $y=5.239 x-7.399$. The dashed line is the RMA for lobes and the mean value of Nelson's (1985) aggregated data with equation $y=5.663 x-8.133$; B) Relation for filtered samples that include only clasts with $a: b$ ratio greater than or equal to 1.5:1. Nelson's (1985) aggregated sample includes all clasts. 
TABLE 3.-Examples of $\mathrm{a}: \mathrm{b}$ clast axial ratios used in studies of periglacial colluvium and documented in the literature.

\begin{tabular}{lll}
\hline \hline \multicolumn{1}{c}{ Author } & \multicolumn{1}{c}{ Environment } & \multicolumn{1}{c}{$\begin{array}{c}\text { Clast Axial Ratio } \\
(a: b)\end{array}$} \\
\hline Giardino and Vitek (1988) & Rock glaciers & $>2: 1$ \\
Nelson (1985) & Periglacial solifluction & $\geq 2: 1$ \\
Perez (1989) & Talus & $1.502: 1-1.922: 1$ \\
Curry and Ballantyne (1999) & Paraglacial debris flows & $>1.5: 1$ \\
Mills (1983) & Colluvium & $\geq 1.5: 1$ \\
Rappol (1985) & Glacial tills and debris flows & $>1.4: 1$ \\
Major (1998) & Debris flows & $1.33: 1$ \\
\hline
\end{tabular}

\section{CONCLUSION}

Multiscale analysis and careful application of formal sampling procedures at each level can enhance both the value of macrofabric data and inter-study comparisons. Clast axial ratio appears to be an important microscale consideration in research designs involving fabrics from colluvial deposits. Our results indicate that the range of clast axial ratios used in fabric work should be restricted to a small interval, and that the ratios should be large ( $>1.5: 1)$. Further work is necessary to establish an optimal range and to ascertain possible relations between fabric strength, axial ratio, clast size and shape, and variations in velocity gradients. Because a large number of variables have the potential to affect fabric characteristics, future research should involve a variety of approaches, including deterministic modeling (Lindsay 1968), laboratory investigations (Harris et al. 1996), statistical simulation (Fisher et al. 1987), and critical field experiments (Millar and Nelson 2001b).

\section{ACKNOWLEDGMENTS}

Fieldwork was supported by the U.S. National Science Foundation (grant number SBR-9305029). We thank G.M. Ashley, D.A. Robinson, J.C.F. Tedrow, K.H. Kjær, and an anonymous reviewer for critical comments on the manuscript, and Joe Stoll for help with Figure 2.

\section{REFERENCES}

ANDREWs, J.T., 1971, Techniques of till fabric analysis: British Geomorphological Research Group Technical Bulletin 6, 43 p.

Bauer, B.O., Veblen, T.T., AND WinkLer, J.A., 1999, Old methodological sneakers: fashion and function in a cross-training era: Association of American Geographers, Annals, v. 89, p. $679-698$

BENN, D.I., 1994, Fabric shape and the interpretation of sedimentary fabric data: Journal of Sedimentary Research, v. A64, p. 910-915.

Bennett, M.R., Waller, R.I., Glasser, N.F., Hambrey, M.J., and Huddart, D., 1999, Glacigenic clast fabrics: genetic fingerprint or wishful thinking?: Journal of Quaternary Science, v. 14 , p. $125-135$.

BerRy, B.J.L., AND BAKer, A.M., 1968, Geographic sampling, in Berry, B.J.L., and Marble, D.F., eds., Spatial Analysis: A Reader in Statistical Geography: Englewood Cliffs, New Jersey, Prentice-Hall, p. 91-100.

BerTRAN, P., 1993, Deformation-induced microstructures in soils affected by mass movements: Earth Surface Processes and Landforms, v. 18, p. 645-660.
Bertran, P., Hétu, B., Texier, J.-P., and Van Stein, H., 1997, Fabric characteristics of subaerial slope deposits: Sedimentology, v. 44, p. 1-16.

Curry, A.M., and Ballantyne, C.K., 1999, Paraglacial modification of glacigenic sediment: Geografiska Annaler, v. 81A, p. 409-419.

DraKe, L.D., 1974, Till fabric controlled by clast shape: Geological Society of America, Bulletin, v. 85 , p. $247-250$.

Fisher, N.I., Lewis, T.L., And Embleton, B.J.J., 1987, Statistical Analysis of Spherical Data: Cambridge, U.K., Cambridge University Press, 329 p.

GiaRdino, J.R., AND ViteK, J.D., 1988, Interpreting the internal fabric of a rock glacier: Geografiska Annaler, v. $70 \mathrm{~A}$, p. $15-25$.

HarRis, C., Davies, M.C.R., And Coutard, J.-P., 1996, An experimental design for laboratory simulation of periglacial solifluction processes: Earth Surface Processes and Landforms, v. 21, p. 67-75.

Haugen, R.K., And Miller, E.J., 1963, A preliminary description of solifluction phenomena in the vicinity of Eagle Summit, Alaska: U.S. Army Corps of Engineers, Cold Regions Research and Engineering Laboratory, Technical Note, 15 p.

HiLl, A.R., 1968, An experimental test of the field technique of till macrofabric analysis: Institute of British Geographers, Transactions, v. 45, p. 93-105.

Iachan, R., 1985, Plane sampling: Statistics \& Probability Letters, v. 3, p. 151-159.

JefFery, G.B., 1922, The motion of ellipsoidal particles immersed in a viscous fluid: Royal Society of London, Proceedings, v. A102, p. 161-179.

KJæR, K.H., AND KRÜGER, J., 1998, Does clast size influence fabric strength?: Journal of Sedimentary Research, v. 68, p. 746-749.

LindSAY, J.F., 1968, The development of clast fabric in mudflows: Journal of Sedimentary Petrology, v. 38, p. 1242-1253.

LunDQvist, G., 1949, The orientation of the block material in certain species of flow earth Geografiska Annaler, v. 31, p. 335-347.

MAJOR, J.J., 1998, Pebble orientation on large, experimental debris-flow deposits: Sedimentary Geology, v. 117, p. 151-164.

Mardia, K.M., 1972, Statistics of Directional Data: New York, Academic Press, 357 p.

Millar, S.W.S., and Nelson, F.E., 2001a, Clast fabric in relict periglacial colluvium, Salamanca Re-entrant, southwestern New York, U.S.A.: Geografiska Annaler, v. 83A, p. 145156

Millar, S.W.S., AND Nelson, F.E., 2001b, Sampling-surface orientation and clast macrofabric in periglacial colluvium: Earth Surface Processes and Landforms, v. 26, p. 523-529.

Mills, H.H., 1983, Clast fabric strength in hillslope colluvium as a function of slope angle: Geografiska Annaler, v. 65A, p. 255-262

Mills, H.H., 1987, Variation in sedimentary properties of colluvium as a function of topographic setting, Valley and Ridge province, Virginia: Zeitschrift für Geomorphologie, v. 31, p. $277-292$.

MiLls, H.H., 1991, Three-dimensional clast orientation in glacial and mass-movement sediments: a compilation and preliminary analysis: U.S. Geological Survey, Open File Repor 90-128, $71 \mathrm{p}$

Nelson, F.E., 1985, A preliminary investigation of solifluction macrofabrics: Catena, v. 12, p 23-33.

Perez, F.L., 1989, Talus fabric and particle morphology on Lassen Peak, California: Geografiska Annaler, v. 71A, p. 43-57.

RAPPOL, M., 1985, Clast-fabric strength in tills and debris flows compared for different environments: Geologie en Mijnbouw, v. 64, p. 327-332.

Schumm, S.A., 1991, To Interpret the Earth; Ten Ways to be Wrong: Cambridge, U.K., Cambridge University Press, $133 \mathrm{p}$.

StARKEY, J., 1977, The contouring of orientation data represented in spherical projection: $\mathrm{Ca}-$ nadian Journal of Earth Sciences, v. 14, p. 268-277.

Stesky, R.M., 1998, SpheriStat User's Manual: Brockville, Ontario, Pangea Scientific Software, $248 \mathrm{p}$.

Till, R., 1974, Statistical Methods for the Earth Scientist: New York, Wiley, 154 p.

Wahrhaftig, C., 1965, Physiographic Divisions of Alaska: U.S. Geological Survey, Professional Paper 482, $52 \mathrm{p}$.

Woodcock, N.H., 1977, Specification of fabric shapes using an eigenvalue method: Geological Society of America, Bulletin, v. 88, p. 1231-1236.

Yамамото, K., 1989, Clast-fabric strength in periglacial slope deposits as a function of clast size and shape: Environmental Science (Hokkaido), v. 12, p. 187-197.

Received 4 April 2002; accepted 28 February 2003. 